\title{
HUBUNGAN MOTIVASI BELAJAR DENGAN HASIL BELAJAR IPS DI SMP KABUPATEN BOGOR
}

\author{
Wahyu Bagja Sulfemi \\ STKIP Muhammadiyah Bogor \\ surel: wahyubagja@gmail.com
}

\begin{abstract}
Abstrak : Penelitian ini dilatar belakangi oleh permasalahan rendahnya hasil belajar siswa pada pembelajaran IPS di SMP Fathu Makkah 01. Tujuan penelitian ini adalah untuk mengetahui apakah terdapat hubungan antara motivasi belajar dengan hasil belajar siswa pada mata pelajaran IPS di SMP FathuMakkah 01 LeuwiliangKabupaten Bogor. Dalam penelitian ini penulis menggunakan metode deskriptif dengan pendekatan kuantitatif, teknik pengumpulan data yang penulis lakukan adalah menggunakan angket (kuesioner) yang diberikan kepada siswa, dengan angket ini penulis mendapatkan data tentang motivasi belajar dengan hasil belajar siswa pada mata pelajaran IPS di SMP Fathu Makkah 01 Kecamatan Leuwiliang Kabupaten Bogor. Setelah data tersebut diperoleh penulis menggunakan rumus presentase dan melakukan uji hipotesis dengan menggunakan product momentdan menggunakan rumus koefisien determin untuk mengetahui kontribusi variabel X dan Y. Subjek penelitian adalah siswa kelas VII sebanyak 120 orang, maka penulis mengambil sampel $25 \%$ dari jumlah tersebut, sehingga jumlah sampel penelitian menjadi 30 siswa yang terdiri dari 17 siswa laki-laki dan 13 siswa perempuan, yang dilaksanakan pada bulan agustus s.d november 2014. Setelah penelitian dilakukan, penulis memperoleh hasil penelitian bahwa terdapat hubungan positif dan signifikan antara motivasi belajar dengan hasil belajar siswa pada mata pelajaran IPS di SMP Fathu Makkah 01 Leuwiliang Kabupaten bogor yaitu $(0,981)$. Kontribusi motivasi belajar dengan hasil belajar siswa pada mata pelajaran IPS adalah $(96,2 \%)$ dan $(3,8 \%)$ ditentukan oleh faktor lain.
\end{abstract}

\section{Kata Kunci : motivasi, hasil belajar, dan pelajaran IPS}

\begin{abstract}
This research was motivated by the problem of the low student learning outcomes in learning Social Sciences at Fathu Makkah Middle School 01. The purpose of this study was to find out whether there was a relationship between learning motivation and student learning outcomes in social studies at Fathu Middle School 01 Leuwiliang District Bogor. In this study the authors used a descriptive method with a quantitative approach, the data collection technique that the writer did was using questionnaires (questionnaires) given to students, with this questionnaire the authors obtained data about learning motivation with student learning outcomes on social studies subjects at Fathu Makkah Middle School 01 Leuwiliang District, Bogor Regency. After the data is obtained the author uses the percentage formula and performs hypothesis testing using product moment and uses the determinant coefficient formula to determine the contribution of variables $\mathrm{X}$ and $\mathrm{Y}$. The research subject is class VII students as many as 120 people, then the authors take a sample of $25 \%$ of that amount, so that the number The study sample was 30 students consisting of 17 male students and 13 female students, which was held in August to November 2014. After the study was conducted, the authors obtained the results of the study that there was a positive and significant relationship between motivation to learn and student learning outcomes in the eyes Social studies at Fathu Makkah Middle School 01 Leuwiliang, Bogor Regency, namely (0.981). The contribution of learning motivation to student learning outcomes in social studies subjects is $(96.2 \%)$ and $(3.8 \%)$ determined by other factors.
\end{abstract}

Keywords: motivation, learning outcomes, and social studies 


\section{PENDAHULUAN}

Dalam kehidupan pribadi atau masyarakat, pendidikan menduduki posisi yang sangat penting, oleh karena itu proses pendidikan pribadi seseorang dapat tumbuh dan berkembang secara baik sesuai dengan yang diharapkan. Menurut Undang-Undang RI Nomor 20 Tahun 2003 tentang sistem pendidikan nasional bab 1 pasal 1 pendidikan adalah usaha sadar dan terencana untuk mewujudkan suasana belajar dan proses pembelajaran agar peserta didik secara aktif mengembangkan potensi dirinya, masyarakat, bangsa dan negara.

Belajar adalah perubahan disposisi atau kemampuan yang dicapai seseorang melalui aktivitas yang di peroleh langsung dari proses pertumbuhan seseorang secara alamiah. ${ }^{1}$ Belajar sebagai konsep mendapatkan pengetahuan dalam prakteknya banyak dianut. Guru bertindak sebagai pengajar yang berusaha memberikan ilmu pengetahuan sebanyak-banyaknya dan peserta didik giat mengumpulkan dan menerimanya.

Belajar adalah proses perubahan perilaku berkat pengalaman dan latihan. ${ }^{2}$ Artinya tujuan kegiatan adalah perubahan tingkah laku, baik yang menyangkut pengetahuan, keterampilan maupun sikap, bahkan meliputi segenap aspek organisme atau pribadi. Belajar adalah perubahan disposisi atau kemampuan yang dicapai seseorang melalui aktivitas yang di peroleh langsung dari proses pertumbuhan seseorang secara alamiah. ${ }^{3}$ Belajar sebagai konsep mendapatkan pengetahuan dalam prakteknya banyak dianut. Guru bertindak sebagai pengajar yang berusaha memberikan ilmu pengetahuan sebanyak-banyaknya dan peserta didik giat mengumpulkan dan menerimanya. Belajar adalah proses perubahan perilaku berkat pengalaman dan latihan. ${ }^{4}$ Artinya tujuan kegiatan adalah perubahan tingkah laku, baik yang menyangkut pengetahuan, keterampilan maupun sikap, bahkan meliputi segenap aspek organisme atau pribadi.

Siswa adalah subjek yang terlibat dalam kegiatan belajar mengajar disekolah. Dalam kegiatan tersebut siswa mengalami tindak mengajar, dan merespon dengan tindak belajar. Pada umumnya semula siswa belum menyadari pentingnya belajar. Berkat informasi guru tentang sasaran belajar, maka siswa mengetahui arti belajar bahan belajar baginya. ${ }^{5}$

Benjamin S. Bloom dalam Dimyati dan Mudjiono menyebutkan ada enam jenis perilaku ranah kognitif sebagai berikut :

1. Pengetahuan, mencapai kemampuan ingatan tentang hal yang telah dipelajari dan tersimpan dalam ingatan. Pengetahuan itu berkenaan dengan fakta, peristiwa, pengertian kaidah, teori, prinsip, atau metode.

2. Pemahaman, mencakup kemampuan menangkap arti dan makna tentang hal yang dipelajari.

3. Penerapan, mencakup kemampuan menerapkan metode dan kaidah untuk menghadapi masalah yang nyata dan baru. Misalnya, menggunakan prinsip.

4. Analisis, mencakup kemampuan merinci suatu kesatuan ke dalam bagian-bagian sehingga struktur keseluruhan dapat dipahami dengan baik. Misalnya mengurangi masalah menjadi bagian yang telah kecil.

\footnotetext{
${ }^{1}$ Agus Suprijono, 2009. Cooperative Learning Teori \& Aplikasi PAIKEM (Cet. 1. Yogyakarta : Pustaka Pelajar).h. 2

${ }^{2}$ Syaiful Bahri Djamarah, 2006. Strategi Belajar Mengajar , ( cet. 3. Jakarta: Rineka Cipta). h. 10

${ }^{3}$ Agus Suprijono, Op. Cit., h. 2

${ }^{4}$ Syaiful Bahri Djamarah, Op. Cit., h. 22h. 10

${ }^{5}$ Dimyati, 2013. Belajar \& Pembelajaran, (cet. 5. Jakarta : Rineka Cipta). 22
} 
5. Sintesis, mencakup kemampuan membentuk suatu pola baru. Misalnya kemampuan menyusun suatu program. ${ }^{6}$

Menurut Agus Suprijono Hasil belajar adalah pola-pola perbuatan, niai-nilai, pengertian-pengertian, sikap-sikap, apresiasi dan keterampilan. ${ }^{7}$ Hasil belajar adalah perubahan perilaku secara keseluruhan bukan hanya salah satu aspek potensi kemanusiaan saja. Begitu pula menurut Hamalik bahwa hasil belajar adalah perubahan tingkah laku pada diri siswa, yang dapat diamati dan diukur dalam bentuk perubahan pengetahuan, sikap dan keterampilan. ${ }^{8}$

Dalam keseluruhan proses pendidikan di sekolah, kegiatan belajar merupakan kegiatan yang paling pokok, ini berarti bahwa berhasil tidaknya pencapaian tujuan pendidikan banyak bergantung kepada bagaimana proses belajar yang dialami oleh siswa sebagai peserta didik. Keberhasilan siswa dalam proses pembelajaran dapat dipengaruhi oleh faktor dari dalam individu maupun dari luar individu. Faktor dari dalam individu meliputi fisik dan psikis, contoh faktor psikis diantaranya adalah motivasi, Belajar yang dilakukan tersebut untuk meraih suatu tujuan tertentu.

Dilihat dari sudut bahasa, Kata "motif" diartikan sebagai daya upaya yang mendorong seseorang untuk melakukan sesuatu. Motif dapat dikatakan sebagai daya penggerak dari dalam dan di dalam subjek untuk melakukan aktivitas-aktivitas tertentu demi mencapai suatu tujuan. Berawal dari kata "motif" tersebut, maka motivasi dapat diartikan sebagai daya penggerak yang telah menjadi aktif.

Menurut Mc. Donald, Motivasi adalah perubahan energi dalam diri seseorang yang ditandai dengan munculnya "feeling" dan didahului dengan tanggapan terhadap adanya tujuan. ${ }^{9}$

Dari pengertian yang dikemukakan Mc. Donald ini mengandung tiga elemen penting yaitu sebagai berikut :

1. Bahwa motivasi itu mengawali terjadinya perubahan energi pada diri setiap individu manusia. Perkembangan motivasi akan membawa beberapa perubahan energi di dalam sistem "neurophysiological" yang ada pada organisme manusia.

2. Motivasi ditandai dengan munculnya, rasa/"feeling", afeksi seseorang. Dalam hal ini motivasi relevan dengan persoalan-persoalan kejiwaan, afeksi dan emosi yang dapat menentukan tingkah laku manusia.

3. Motivasi akan dirangsang karena adanya tujuan. Jadi motivasi dalam hal ini merupakan respons dari suatu aksi, yakni tujuan. Motivasi memang muncul dari dalam diri manusia, tetapi kemunculannya karena terangsang/terdorong oleh adanya unsur lain, dalam hal ini adalah tujuan. Tujuan ini akan menyangkut soal kebutuhan.

Dengan ke tiga elemen di atas, maka dapat dikatakan bahwa motivasi itu sebagai sesuatu yang kompleks. Motivasi akan menyebabkan terjadinya suatu perubahan energi yang ada pada diri manusia. Semua ini didorong karena adanya tujuan, kebutuhan dan keinginan. berikut :

Fungsi Motivasi Dalam Belajar terbagi menjadi tiga ${ }^{10}$ macam yaitu sebagai

1. Mendorong peserta didik untuk berbuat

2. Menentukan arah kegiatan pembelajaran yakni ke arah tujuan belajar yang hendak dicapai.

\footnotetext{
${ }^{6}$ Dimyati, Op. Cit., h. 26-27

${ }^{7}$ Agus Suprijono, Op. Cit., h. 5

${ }^{8}$ Hamalik, 2011, kurikulum dan pembelajaran . (Jakarta : Bumi Aksara). h. 155

${ }^{9}$ Sardiman, 2011. Interaksi \& Motivasi Belajar Mengajar, (cet. 19. Jakarta : Rajawali Pers). h. 73

${ }^{10}$ Agus Suprijono, 2009. Cooperative Learning Teori \& Aplikasi PAIKEM (Cet. 1. Yogyakarta :

Pustaka Pelajar). h. 163-164
} 
3. Menyeleksi kegiatan pembelajaran.

Disamping itu, terdapat fungsi-fungsi lain yaitu motivasi dapat berfungsi sebagai pendorong usaha dan pencapaian prestasi, seseorang melakukan suatu usaha karena adanya motivasi. Adanya motivasi yang baik dalam belajar akan menunjukan hasil yang baik. Dengan adanya usaha yang tekun dan terutama didasari adanya motivasi, maka seseorang yang belajar akan dapat melahirkan prestasi yang baik. Intensitas motivasi seorang siswa akan sangat menentukan tingkat pencapaian prestasi belajarnya. ${ }^{11}$

Menurut Dimyati dan Mudjiono ada dua ${ }^{12}$ jenis motivasi adalah sebagai berikut :

1. Motivasi Primer. Motivasi primer adalah motivasi yang didasarkan pada motif-motif dasar.

Motif-motif dasar tersebut umumnya berasal dari segi biologis atau jasmani manusia.

2. Motivasi Sekunder . Motivasi sekunder adalah motivasi yang dipelajari, motivasi sekunder memegang peranan penting bagi kehidupan manusia.

Menurut Syaiful Bahri Djamarah ada dua ${ }^{13}$ yaitu Motivasi dilihat dari dua sudut pandang, yakni motivasi yang berasal dari dalam diri pribadi seseorang yang disebut "motivasi intrinsik" dan motivasi yang berasal dari luar diri seseorang yang disebut "motivasi ekstrinsik".

1. Motivasi Intrinsik. Yang dimaksud dengan motivasi intrinsik adalah motif-motif yang menjadi aktif atau berfungsinya tidak perlu dirangsang dari luar, karena dalam setiap diri individu sudah ada dorongan untuk melakukan sesuatu.

2. Motivasi Ekstrinsik. Motivasi ekstrinsik adalah motif-motif yang aktif dan berfungsi karena adanya perangsang dari luar.

Motivasi berprestasi memegang peranan penting, keberhasilan belajar sering disebabkan adanya motivasi yang kuat. Sebaliknya, kegagalan belajar juga sering disebabkan karena tidak ada atau kurang motivasi. Motivasi berperan memberikan gairah atau semangat dalam belajar, sehingga siswa yang bermotivasi kuat memiliki banyak energi untuk melakukan kegiatan belajar. Ilmu Pengetahuan Sosial (IPS) merupakan salah satu mata pelajaran yang dipelajari oleh siswa tingkat Sekolah Menengah Pertama (SMP). Pelajaran Ilmu Pengetahuan Sosial (IPS) di SMP masih bersifat umum, yaitu gabungan antara geografi, sejarah, sosiologi, antropologi, ekonomi yang terpadu. Pembelajaran Ilmu Pengetahuan Sosial (IPS) dikatakan berhasil apabila semua tujuan pembelajaran yang telah ditentukan dapat tercapai, yang terungkap dalam hasil belajar Ilmu Pengetahuan Sosial (IPS).

Rendahnya hasil belajar menunjukan adanya indikasi terhadap rendahnya kinerja belajar siswa dan kemampua guru dalam mengelola pembelajaran yang berkualitas. Untuk mengetahui mengapa hasil belajar siswa tidak seperti yang diharapkan, tentu guru perlu merefleksi diri untuk dapat mengetahui faktor-faktor ketidak berhasilan siswa dalam pelajaran. Sebagai guru yang baik dan profesional, maka diperlukan suatu optimalisasi pembelajaran dalam meningkatkan hasil belajar peserta didik serta dapat membuat peserta didik aktif dalam menemukan dan membangun pemahaman.

Adapun rumusan masalah dalam penelitian ini adalah sebagai berikut Bagaimana gambaran motivasi belajar siswa pada mata pelajaran IPS di SMP Fathu Makkah 01 Kecamatan Leuwiliang kabupaten Bogor? (2) Bagaimana gambaran belajar siswa pada mata pelajaran IPS di SMP Fathu Makkah 01 Kecamatan Leuwiliang kabupaten Bogor? (3) Apakah terdapat hubungan antara motivasi belajar siswa dengan hasil belajar siswa pada mata pelajaran IPS di SMP Fathu Makkah 01 Kecamatan Leuwiliang kabupaten Bogor?

${ }^{11}$ Sardiman, Op. Cit., h. 85-86

12 Dimyati, 2013. Belajar \& Pembelajaran, (cet. 5. Jakarta : Rineka Cipta). h. 86-88

${ }^{13}$ Syaiful Bahri Djamarah, 2011. Psikologi Belajar.(cet. 3. Jakarta : Rineka Cipta). h. 149-151 


\section{METOLOGI PENELITIAN}

Dalam melakukan penelitian, peneliti dapat memilih jenis metode apa yang akan digunakan dalam melaksanakan penelitian. Metode penelitian pada tesis ini adalah metode survey dengan bentuk korelasional, bertujuan untuk menguji hipotesis yang menyatakan ada tidaknya hubungan antara variable bebas motivasi belajar (X1) dan terikat hasil belajar (Y).

Dalam penelitian ini yang menjadi populasi adalah siswa-siswi SMP Fathu Makkah 01 Kecamatan Leuwiliang Kabupaten Bogor sebayak 120 siswa dan penulis mengambil sampel $25 \%$ dari jumlah populasi, sehingga jumlah sampel penelitian menjadi 30 siswa.

Teknik analisis yang yang digunakan adalah korelasional dengan teknik analis statistik mengenai hubungan antara dua variabel atau lebih. Analisis ini digunakan untuk mengetahui korelasi anatara variabel dengan rumus kolerasi product moment.

\section{HASIL DAN PEMBAHASAN}

Untuk menganalisis data penulis mendeskripsikan data dengan menggunakan angket yang disusun penulis terdiri dari 30 item pernyataan untuk variabel X (Motivasi Belajar) dan 35 item pernyataan untuk variabel Y (Hasil Belajar Siswa Pada Mata Pelajaran IPS) adapun hasil dari instrumen tersebut terdapat 2 item pernyataan yang tidak valid yaitu item nomor 17 dan 30 pada angket variabel X (Motivasi Belajar) dan untuk variabel Y (Hasil Belajar Siswa Pada Mata Pelajaran IPS) terdapat 5 item pernyataan yang tidak valid yaitu item nomor 31,32,33,34,35.

Angket yang disusun terdiri dari dari 30 pernyataan mengenai Motivasi Belajar (sebagai variabel X) dan 35 pernyataan mengenai Hasil Belajar Siswa Pada Mata pelajaran IPS (sebagai variabel Y) yang disebar ke 30 responden Siswa SMP Fathu Makkah 01 Leuwiliang Kabupaten Bogor.

Untuk menentukan nilai kuantitatif motivasi belajar adalah dengan menjumlahkan skor jawaban angket dari responden. Dari data (range) yang didapat nilai terbesar 80 dan terkecil 35, dengan rentang data 45, Kelas Interval $(\mathrm{K})$ yaitu $=5,874$ (dibulatkan menjadi 6, Panjang Interval (P) yaitu 7,5 Modus (Mo) yaitu 72,65, Median (Md) yaitu 75,4, dan Mean (Me) yaitu 67,16. Berikut adalah taber Daftar Distribusi Frekuensi Motivasi Belajar

Tabel Daftar Distribusi Frekuensi Motivasi Belajar

\begin{tabular}{|c|c|c|c|c|c|}
\hline Interval Kelas & $\mathrm{F}$ & $\mathrm{X}$ & $\mathrm{X}^{\mathbf{2}}$ & $\mathrm{F} . \mathrm{X}$ & $\mathrm{F}^{\mathbf{2}}$ \\
\hline $42-48$ & 2 & 45 & 2025 & 90 & 4050 \\
\hline $49-55$ & 2 & 52 & 2704 & 104 & 5408 \\
\hline $56-62$ & 2 & 59 & 3481 & 118 & 6962 \\
\hline $63-69$ & 4 & 66 & 4356 & 264 & 17424 \\
\hline $70-76$ & 11 & 73 & 5329 & 803 & 58619 \\
\hline $77-83$ & 7 & 80 & 6400 & 560 & 44800 \\
\hline Jumlah & $\mathbf{3 0}$ & $\mathbf{4 1 3}$ & $\mathbf{2 5 7 3 9}$ & $\mathbf{2 0 1 5}$ & $\mathbf{1 4 0 1 5 1}$ \\
\hline
\end{tabular}

Besar simpangan baku penyebaran data skor motivasi belajar dapat dilihat pada tabel dibawah ini 
Tabel Distribusi Frekuensi Relative Motivasi Belajar

\begin{tabular}{|c|c|c|}
\hline Interval Kelas & Frekuensi & F.Relative \\
\hline $35-41$ & 2 & $6,67 \%$ \\
\hline $42-48$ & 2 & $6,67 \%$ \\
\hline $49-55$ & 2 & $6,67 \%$ \\
\hline $56-62$ & 2 & $6,67 \%$ \\
\hline $63-69$ & 4 & $13,33 \%$ \\
\hline $70-76$ & 11 & $36,67 \%$ \\
\hline $77-83$ & 7 & $23,33 \%$ \\
\hline
\end{tabular}

Untuk memperjelas data yang terdapat pada tabel, dibawah ini disajikan histogram data gambar mengenai motivasi belajar sebagai berikut

\section{Gambar Histogram Motivasi Belajar}

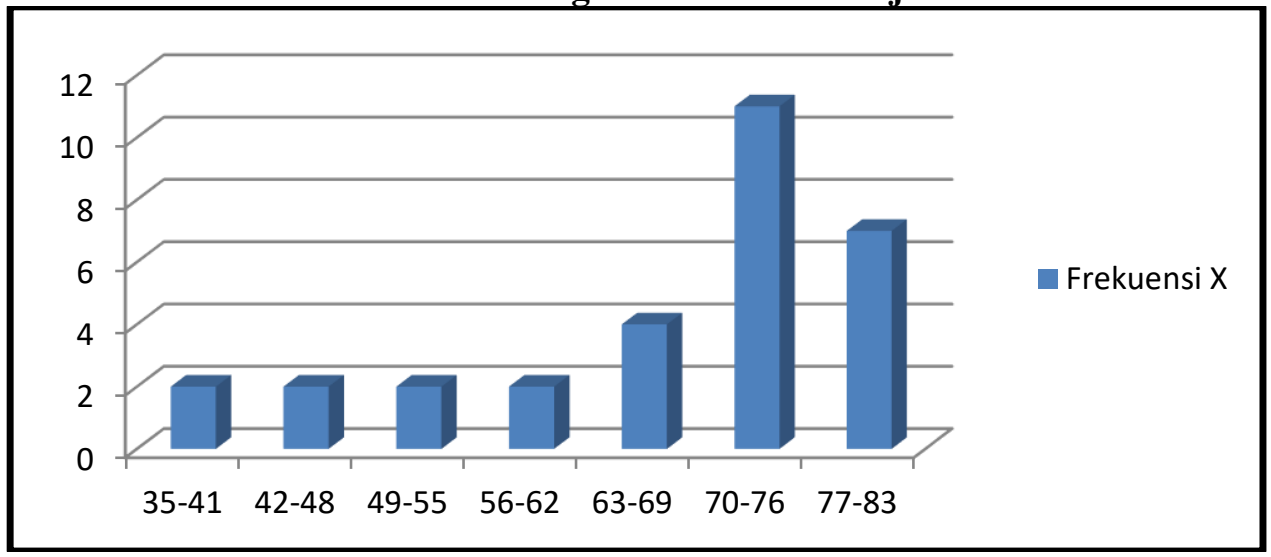

Berdasarkan gambar diatas, dapat dilihat bahwa banyaknya motivasi belajar berkisar antara $70-76$. Untuk menentukan nilai kuantitatif hasil belajar siswa pada mata pelajaran IPS, siswa di berikan 35 item pernyataan mengenai hasil belajar siswa mata pelajaran IPS yang disebar ke 30 siswa. Dari data di dapat Rentang Data (R) 54, Kelas Interval K 5,874 (dibulatkan 6), Panjang Interval (P) 9 d. Modus (Mo) 74,8, Median (Md) 80,25 dan Mean (Me) 73,3 . Berikut adalah tebel daftar distribusi frekuensi hasil belajar siswa mata pelajaran IPS

Tebel Daftar Distribusi Frekuensi Hasil Belajar Siswa Mata Pelajaran IPS

\begin{tabular}{|c|c|c|c|c|c|}
\hline Interval Kelas & $\mathrm{F}$ & $\mathrm{X}$ & $\mathrm{X} 2$ & $\mathrm{FX}$ & $\mathrm{FX} 2$ \\
\hline $36-44$ & 4 & 40 & 1600 & 160 & 6400 \\
\hline $45-53$ & 2 & 49 & 2401 & 98 & 4802 \\
\hline $54-62$ & 2 & 58 & 3364 & 116 & 6728 \\
\hline $63-71$ & 2 & 67 & 4489 & 134 & 8978 \\
\hline $72-80$ & 8 & 76 & 5776 & 608 & 46208 \\
\hline $81-89$ & 5 & 85 & 7225 & 425 & 36125 \\
\hline $90-98$ & 7 & 94 & 8836 & 658 & 61852 \\
\hline Jumlah & 30 & 469 & 33691 & 2199 & 171093 \\
\hline
\end{tabular}


Distribusi Frekuensi Relative Hasil Belajar Siswa

\begin{tabular}{|c|c|c|}
\hline Interval Kelas & Frekuensi & F Relative \\
\hline $36-44$ & 4 & $13,33 \%$ \\
\hline $45-53$ & 2 & $6,66 \%$ \\
\hline $54-62$ & 2 & $6,66 \%$ \\
\hline $63-71$ & 2 & $6,66 \%$ \\
\hline $72-80$ & 8 & $26,66 \%$ \\
\hline $81-89$ & 5 & $16,66 \%$ \\
\hline $90-98$ & 7 & $23,33 \%$ \\
\hline Jumlah & 30 & $100 \%$ \\
\hline
\end{tabular}

Berdasarkan gambaran di atas, dapat dilihat bahwa nilai hasil belajar siswa berkisar antara dalam Gambar Diagram Batang Hasil Belajar Siswa berikut ini

\section{Gambar Diagram Batang Hasil Belajar Siswa}

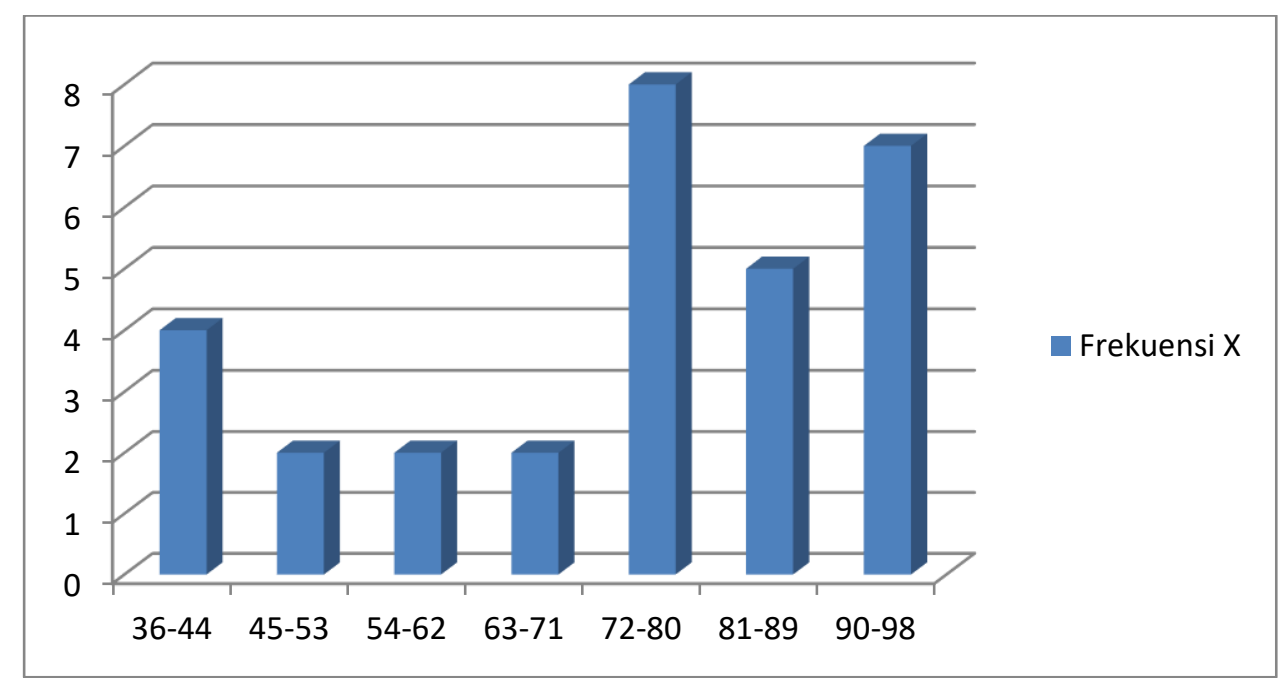

Berdasarkan gambar diatas, dapat dilihat bahwa banyaknya hasil belajar siswa pada mata pelajaran IPS berkisar antara $72-80$.

Data yang sudah terkumpul kemudian dicari korelasi motivasi belajar dengan hasil belajar siswa pada mata pelajaran IPS, maka dilakukan perhitungan korelasi product moment. Setelah diketahui antara kedua variabel diatas melalui statistik pearson product moment, maka selanjutnya dimasukkan ke dalam korelasi pearson product moment dengan diketahui data sebagai berikut : $\mathrm{N}=30, \sum \mathrm{X}=2025, \sum \mathrm{Y}=2170, \sum X^{2}=142509, \sum Y^{2}=165966, \sum \mathrm{XY}=$ 153556, $\left(\sum X\right)^{2}=4108729$ dan $\left(\sum Y\right)^{2}=4708900$. Maka setelah dilakukan dengan menggunakan korelasi pearson product moment didapat $r_{x y}=0,98$. Untuk mengetahui keberartian korelasi variabel $\mathrm{X}$ dan variabel $\mathrm{Y}$ dapat diketahui dengan menggunakan uji t. Setelah melakukah hitungan maka diperoleh t sebesar 26,672.

Dengan demikian didapat nilai $\mathrm{t}_{\text {hitung }} 26,672$ dan $\mathrm{t}_{\text {tabel }}$ pada taraf signifikan 0,05 dengan $\mathrm{dk}=$ $\mathrm{N}-2=30-2=28$ adalah 2,048. artinya $\mathrm{t}_{\text {hitung }}(26,672)>\mathrm{t}_{\text {tabel }}(2,048)$ maka koefisien korelasi adalah signifikan. Dengan demikian, terdapat korelasi positif antara motivasi belajar dengan hasil belajar siswa. Kemudian untuk mengetahui seberapa besar kontribusi variabel $\mathrm{X}$ terhadap variabel Y dapat ditentukan dengan rumus koefisien diterminan maka KD diperoleh 96,2 \%. Dari hasil yang diperoleh peneliti dapat ditarik kesimpulan bahwa terdapat korelasi hasil belajar siswa ditentukan oleh motivasi belajar sebesar $96,2 \%$ dan 3,8 \% berkorelasi dengan faktor lainnya. 
Mengacu pada permasalahan yang telah dirumuskan. Masalah tersebut mempertanyakan apakah terdapat korelasi positif antara motivasi belajar dengan hasil belajar siswa pada mata pelajaran IPS. Berdasarkan hasil penelitian yang penulis lakukan, dapat dikemukakan bahwa terdapat korelasi yang positif antara variabel X (motivasi belajar) dengan variabel $\mathrm{Y}$ (hasil belajar siswa) karena hipotesis . Alternatif $\left(\mathrm{H}_{\mathrm{a}}\right)$ diterima dengan $\mathrm{r}_{\mathrm{xy}}$ yaitu 0,981 lebih besar dari $\mathrm{r}_{\text {tabel }}$ dengan taraf signifikan $0,05 \%$ yaitu 0,361 .

Setelah itu dilanjutkan mengukur besar kecilnya antara variabel $\mathrm{X}$ dan $\mathrm{Y}$ ditentukan dengan rumus koefisien diterminan dengan hasil 96,2\%, artinya korelasi motivasi belajar dengan hasil belajar siswa pada mata pelajaran ips sebesar $96,2 \%$ dan sisanya 3,8\% berkorelasi dengan faktor lainnya. Selanjutnya untuk menguji keberartiannya maka dilakukan uji $t_{\text {hitung. }}$. Berdasarkan hasil pengujian $t_{\text {hitung }}$ sebesar 26,672 dan $t_{\text {tabel }}$ dengan derajat kebebasan $(\mathrm{dk})=30-2=28$ dengan taraf signifikan $=0,05 \%$ sebesar 2,048. Hal ini berarti $t_{\text {hitung }}$ lebih besar dari $t_{\text {tabel }} 26,672>$ 2,048. Hasil pengujian terhadap koefisien korelasi yang diperoleh dari hasil perhitungan bahwa $\mathrm{r}_{\mathrm{xy}}$ 0,981. Dengan demikian $\mathrm{H}_{0}$ ditolak $\mathrm{H}_{\mathrm{a}}$ diterima yang berarti terdapat korelasi antara motivasi belajar dengan hasil belajar siswa pada mata pelajaran ips. Hal tersebut terbukti dengan hasil $\mathrm{r}_{\text {hitung }}$ lebih besar dari pada $\mathrm{r}_{\text {tabel. }}$.

Penelitian di SMP Fathu Makkah 01 Leuwiliang Kabupaten Bogor yaitu pada persoalan korelasi motivasi belajar dengan hasil belajar siswa pada mata pelajaran IPS. Kemudian mengajukan asumsi yang penulis tuangkan pada penelitian ini, selanjutnya penulis menyebarkan angket atau kuesioner yang penulis sebarkan kepada 30 siswa.

Dari hasil perhitungan product moment diatas diketahui bahwa $r_{\text {hitung }}$ sebesar 0,981 dan $r_{\text {tabel }}$ pada $\mathrm{N}=30$ dan taraf signifikan $0,05 \%$ adalah 0,361 dan nilai $t_{\text {hitung }}$ lebih besar dari pada $t_{\text {tabel }}$ yakni 26,672 > 2,048. Kriteria pengujian, yaitu :Tolak $\mathrm{H}_{0}$, Jika $t_{\text {hitung }}>\mathrm{t}_{\text {tabel }}$ Tolak $\mathrm{H}_{\mathrm{a}}$, Jika $\mathrm{t}_{\text {hitung }}<\mathrm{t}_{\text {tabel. }}$. Tolak $\mathrm{H}_{0}$ (Hipotesis nol $)=$ Untuk menyatakan tidak adanya Korelasi antara dua variabel $(\mathrm{X}$ dan $\mathrm{Y})$. Tolak $\mathrm{H}_{\mathrm{a}}$ (Hipotesis alternatif $)=$ Untuk menyatakan adanya korelasi antara dua variabel (X dan $\mathrm{Y})$.

Dengan demikian nilai $\mathrm{r}$ product moment terdapat korelasi antara motivasi belajar dengan hasil belajar siswa pada mata pelajaran IPS , dan $\mathrm{t}_{\text {tabel }}$ pada perhitungan taraf signifikan $0,05 \%$ dengan $\mathrm{df}=\mathrm{N}-2=28$ juga terdapat korelasi positif, terbukti $t_{\text {hitung }} 26,672$ lebih besar dari pada $t_{\text {tabel }} 2,048$, yakni 26,672 > 2,048 yang berarti $\mathrm{H}_{0}$ ditolak sedangkan $\mathrm{H}_{\mathrm{a}}$ diterima. Untuk menyatakan dan menentukan bobot tingkat korelasi .

Motivasi belajar dengan hasil belajar siswa pada mata pelajaran IPS, penulis menggunakan kriteria besarnya koefisien. Berdasarkan kriteria tingkat interpretasi data diatas, diketahui $\mathbf{r}_{\text {hitung }}$ adalah 0,981 yang berarti berada di antara 0,80 sampai dengan 1,000 maka dapat dikatakan bahwa motivasi belajar dengan hasil belajar siswa pada mata pelajaran IPS di SMP Fathu Makkah 01 Leuwiliang Kabupaten Bogor mempunyai kriteria sangat kuat.

Dengan demikian bahwa Prestasi belajar adalah hasil usaha belajar yang berupa nilai-nilai sebagai ukuran kecakapan dari usaha belajar yang telah dicapai seseorang, prestasi belajar ditunjukan dengan jumlah nilai raport atau tes nilai sumatif. Sebenarnya prestasi belajar peserta didik tidak selamanya merupakan gambaran dari kemampuan yang sebenarnya. Dengan demikian prestasi belajar di sekolah tidak selalu di wujudkan dengan kecakapan-kecakapan, namun kecakapan itu hanya merupakan sebagian dari unsur pertumbuhan, dan pembentukan dari suatu prestasi belajar.

Prestasi belajar harus memiliki tiga aspek, yaitu kognitif, affektif dan psikomotorik, karena Prestasi belajar adalah hasil yang dicapai sebaik-baiknya pada seorang anak dalam pendidikan baik yang dikerjakan atau bidang keilmuan. Semua pelaku pendidikan (siswa, orang tua dan guru) pasti menginginkan tercapainya sebuah prestasi belajar yang tinggi, karena prestasi belajar yang tinggi merupakan salah satu indikator keberhasilan proses belajar. Namun kenyataannya tidak semua siswa mendapatkan prestasi belajar yang tinggi dan terdapat pula siswa yang mendapatkan prestasi belajar yang rendah. Tinggi dan rendahnya prestasi belajar yang diperoleh siswa dipengaruhi banyak faktor.

Kompetensi merupakan kemampuan seseorang yang meliputi pengetahuan, keterampilan dan sikap yang dapat diwujudkan dalam hasil kerja nyata yang bermanfaat bagi diri dan 
lingkungannya. Kemampuan pedagogik guru merupakan keterampilan seorang guru dalam melaksanakan tugasnya disekolah sebagai pendidik, dengan indikator : (1) kemampuan guru membuat Rencana Program Pembelajaran, (2) kemampuan guru dalam menyampaikan pelajaran, (3) kemampuan guru berinovasi dalam proses pembelajaran, (4) kemampuan guru dalam menguasai media dan bahan ajar (5) komunikasi seorang guru dengan siswa.

Disamping itu pula guru memiliki tugas-tugas yang berpusat pada : (a) mendidik dengan titik berat memberikan arah dan motivasi pencapaian tujuan baik jangka pendek maupun jangka panjang, (b) memberikan fasilitas pencapaian tujuan melalui pengalaman belajar yang memadai, (c) membantu perkembangan aspek-aspek pribadi seperti sikap, nilai-nilai dan penyesuaian diri. Demikianlah dalam proses belajar-mengajar guru tidak terbatas sebagai penyampai ilmu pengetahuan akan tetapi lebih dari itu, ia bertanggung jawab akan keseluruhan perkembangan kepribadian siswa. Ia harus menciptakan proses belajar yang sedemikian rupa sehingga dapat merangsang siswa untuk belajar secara aktif dan dinamis dalam memenuhi kebutuhan dan menciptakan tujuan.

Kemampuan mengelola pembelajaran dapat dianalisis kedalam beberapa kompetensi yang mencakup pemahaman peserta didik, perancangan, dan pelaksanaan pembelajaran, evaluasi hasil belajar, dan pengembangan peserta didik untuk mengaktualisasikan berbagai potensi yang dimilikinya sehingga tujuan pembelajaran bisa tercapai.

Dalam memberikan pelajaran seorang guru harus dapat memilih bagian pelajaran yang perlu diberikan tekanan perhatian dari siswa dan sementara itu harus dapat menentukan bagian pelajaran yang tidak terlalu penting. Sebab persepsi siswa tentang kemampuan pedagogik guru, juga dipengaruhi sikap siswa terhadap guru itu sendiri, bidang studi yang diajarkan, serta motivasi dalam diri sendiri, ketiga hal tersebut adalah beberapa diantara indikator terjadinya suatu tanggapan terhadap objek yang diterima siswa dan saling terkait serta dapat terungkap dalam tingkah laku yang ditampakkan.

Sehingga prestasi Belajar Siwa di SMP SMP Fathu Makkah 01 Leuwiliang Kabupaten Bogor mata Pelajaran Ilmu Pengetahuan Sosial (IPS), dimana IPS adalah sebuah perangkat pembelajaran yang mempelajari tentang fakta, peristiwa, konsep dan generalisasi yang mengacu pada nilai, sikap serta pengetahuan sosial dalam ranah pendidikan, baik dalam ruang lingkup keluarga, masyarakat, lingkungan serta bangsa dan Negara dapat tercapai

\section{KESIMPULAN IMPLIKASI DAN SARAN}

\section{A. Kesimpulan}

Berdasarkan hasil pengujian hipotesis penelitian, maka dapat ditarik kesimpulan sebagai hasil penelitian ini adalah sebagai berikut :

1. Hasil penelitian membuktikan bahwa motivasi belajar di SMP Fathu Makkah 01 Leuwiliang Kabupaten Bogor memiliki kriteria diatas rata-rata sebesar 36,67\%, berkriteria dibawah rata-rata sebesar $6,67 \%$. Dilihat dari rata-ratanya sebesar $67,16 \%$ yang termasuk kriteria tinggi. Dengan demikian dapat disimpulkan bahwa motivasi belajar siswa pada mata pelajaran IPS di SMP Fathu Makkah 01 Leuwiliang Kabupaten Bogor termasuk dalam kriteria tinggi.

2. Berdasarkan hasil penelitian di atas, bahwa hasil belajar siswa pada mata pelajaran IPS dalam kriteria diatas rata-rata sebesar 26,66 \% dan kriteria dibawah rata-rata sebesar 6,66\%. Dilihat dari rata-ratanya sebesar $73,3 \%$ yang termasuk kriteria tinggi. Dengan demikian dapat disimpulkan bahwa hasil belajar siswa pada mata pelajaran IPS di SMP Fathu Makkah 01 Leuwiliang Kabupaten Bogor termasuk dalam kriteria tinggi.

3. Berdasarkan hasil pengujian $t_{\text {hitung }}$ sebesar 26,672 dengan derajat kebebasan $(\mathrm{dk})=\mathrm{N}-2$ dan $\alpha=0,05 \%$ sebesar 2,048. Hal ini berarti $t_{\text {hitung }}(26,672)>t_{\text {tabel }}(2,048)$. Hasil kolerasi yang diperoleh dari hasil perhitungan product moment bahwa $r_{\mathrm{xy}}=0,981$ adalah signifikan. Dengan demikian $\mathrm{H}_{0}$ ditolak sedangkan $\mathrm{H}_{\mathrm{a}}$ diterima yang berarti terdapat korelasi yang signifikan antara motivasi belajar dengan hasil belajar siswa pada mata pelajaran IPS di SMP Fathu Makkah 01 Leuwiliang Kabupaten Bogor. 


\section{B. Implikasi}

Motivasi belajar siswa pada mata pelajaran IPS di SMP Fathu Makkah 01 Leuwiliang Kabupaten Bogor termasuk dalam kriteria tinggi dan Hasil belajar siswa pada mata pelajaran IPS di SMP Fathu Makkah 01 Leuwiliang Kabupaten Bogor termasuk dalam kriteria tinggi. Motivasi belajar adalah keseluruhan daya penggerak baik dari dalam diri maupun dari luar dengan menciptakan serangkaian usaha untuk menyediakan kondisi-kondisi tertentu yang menjamin kelangsungan dan memberikan arah pada kegiatan sehingga tujuan yang dikehendaki oleh subjek itu dapat tercapai. Dalam kegiatan belajar, motivasi dapat dikatakan sebagai keseluruhan daya penggerak di dalam diri siswa yang menimbulkan kegiatan belajar, yang menjamin kelangsungan dari kegiatan belajar dan yang memberikan arahan pada kegiatan belajar, sehingga tujuan yang dikehendaki oleh subjek belajar itu dapat tercapai.

Peranannya yang khas adalah dalam hal penumbuhan gairah, merasa senang, dan semangat untuk belajar. Siswa yang memiliki motivasi kuat, akan mempunyai banyak energi untuk melakukan kegiatan belajar, hasil belajar akan optimal apabila ada motivasi yang tepat, kemudian dalam korelasi nya dengan kegiatan belajar, yang penting bagaimana menciptakan kondisi atau suatu proses yang mengarahkan siswa itu melakukan aktivitas belajar, dalam hal ini peran guru sangat penting. Oleh karena itu guru melakukan usaha-usaha untuk dapat menumbuhkan dan memberikan motivasi agar siswa melakukan aktivitas belajar dengan baik, untuk dapat belajar dengan baik diperlukan proses dan motivasi yang baik pula. Dengan demikian, terdapat korelasi antara motivasi belajar dengan hasil belajar siswa pada mata pelajaran IPS di SMP Fathu Makkah 01. Semakin tinggi motivasi belajar siswa, semakin tinggi hasil belajar siswa SMP Fathu Makkah 01.

\section{Saran}

Setelah menyimpulkan hasil penelitian, adapun saran yang disampaikan peneliti adalah :

1. Untuk hasil belajar perlu meningkatkan motivasi, justru itu perlu dilakukan penelitian lanjutan tentang pengembangan motivasi belajar.

2. Guru perlu menjadi motivator siswa, sehingga siswa terdorong untuk memiliki keinginan yang kuat untuk belajar, berprestasi dan melakukan yang terbaik.

3. Dalam rangka peningkatan kualitas siswa terutama pada aspek motivasi dalam belajar hendaknya pihak sekolah meningkatkan sarana dan prasarana pendidikan sehingga siswa bisa meningkatkan hasil belajar yang lebih baik.

\section{DAFTAR PUSTAKA}

Arsyad, dan Sulfemi, Wahyu Bagja. (2014). Minat Siswa Tentang Keadministrasian dengan Hasil Belajar Administrasi Perkantoran. Edutecno. 9 (2), 40-50.

Badar, Dadan Samsul dan Sulfemi, Wahyu Bagja. (2014). Pengaruh Rasa Percaya Diri dan Motivasi Berprestasi Terhadap Kinerja di Kecamatan Ciampea Kabupaten Bogor. Edutecno. 10 (1), 1-10

Bahri, Syaiful, (2011). Psikologi Belajar. Jakarta : Rineka Cipta.

Bahri, Syaiful. (2006). Stategi Belajar Mengajar. Jakarta : Rineka Cipta

Dimyati, (2006). Strategi Belajar dan Pembelajaran. Jakafia: Rineka Cipta 
Fajartriani, Tia dan Sulfemi, Wahyu Bagja. (2014).Pengaruh Motivasi Kerja Guru dan Iklim Organisasi Terhadap Kinerja Guru SMA Negeri di Kecamatan Cigudeg. Edutecno. 8 (1), 17-26

Karsiwan, Wawan dan Sulfemi, Wahyu Bagja. (2016). Hubungan Penerimaan Diri Dengan Kinerja Guru SD Di Kecamatan Pamijahan Kabupaten Bogor Edutecno. 15. (1). 1-10.

Harnalik, (2011). Kurikulum dan Pembelajaran Jakarta : Bumi Aksara

Moh. Nazir, (2012). Metodologi Penelitian. Bogor : Ghalia Indonesia

Muhibbin, Syah, (2011). Psikologi Pendidikan Dengan pendekatan Baru. Banilng: PT.Remaja Rosdakarya.

Ronald E. Walpole, (1992). Pengantar Statistik. Jakarta: PT Gramedia Pusuka Utama.

Sardiman, (2011). Interalmi \& Motivasi Belajar Mengajar. Jakarta : Rajawali Pers

Slameto, (2007). Belajar dan Faktor Yang Mempengaruhi. Jakafia : Rineka Cipta

Sudijono, Anas. 2008. Pengantar Statistik Pendidikan. Jakarta : PT. Raja Grafindo Persada.

Sudjana, (2005). Metoda Statistik. Bandung : PT. Tarsito

Sugiyono, (2011). Metode Penelitian Administrasi. Bandung : fufabeta

Suharsimi Arikunto, (2006). Prosedur Penelitian Suatu Pendekatan. Praktik. Jakarta : Renika Crpta.

Suprijono, Agus. (2009). Cooperative Learning Teori dnn Aplilasi PAIKEM. Jogiakarta :Pustaka Pelajar.

Supranto J, (2008). Statistik Teori dan Aplilasi. Jakarta : Erlangga Aksar

Yusfiriadi dan Sulfemi, Wahyu Bagja. (2012). Penyelewangan Dana Dalam Dunia Pendidikan. Fascho 1 (1), 1-9.

Sulfemi, Wahyu Bagja. (2013). Pengaruh Persepsi Siswa atas Kemampuan Pedagogik Guru dan Motivasi Belajar Siswa Terhadap Prestasi Belajar Ilmu Pengetahuan Sosial Siswa (Survei di SMK Swasta Kabupaten Bogor). Edutecno. 7 (2), 17-26.

Sulfemi, Wahyu Bagja. (2015). Pengaruh Metode Pembelajaran Kontekstual dan Penggunaan Media Video Pendidikan Terhadap Hasil Belajar IPS. Edutecno. $13(2), 1-10$.

Sulfemi, Wahyu Bagja. (2015). Challenges Of Indonesian Teacher Competence in dealing with Asean Economic Cummunity (AEC). Engglis Forum. 1 (1), 6979

Sulfemi, Wahyu Bagja. (2016). Hubungan Persepsi Peserta Didik Tentang Kompetensi Guru Mata Pelajaran Sejarah dengan Hasil Belajar Mata Pelajaran Sejarah di Kelas X SMA Negeri 1 Pamijahan Kabupaten Bogor. Fascho, 5 (2), 52-70. 
Sulfemi, Wahyu Bagja. (2016). Hubungan antara Persepsi Guru pada Kepemimpian Kepala Sekolah dan Motivasi Guru dengan Kinerja guru dalam Proses Pembelajaran di SMA Negeri 1 Ciomas. Fascho : Kajian Pendidikan dan Sosial Kemasyarakatan, 5 (1), 36-55.

Sulfemi, Wahyu Bagja. (2016). Kompetensi Profesionalisme Guru Indonesia dalam Menghadapi MEA. Prosiding Seminar Nasional STKIP Muhammadiyah Bogor. 1 (1), 62-77.

Sulfemi, Wahyu Bagja. (2016). Hubungan antara Persepsi Guru pada Kepemimpian Kepala Sekolah dan Motivasi Guru dengan Kinerja guru dalam Proses Pembelajaran di SMA Negeri 1 Ciomas. Fascho : Kajian Pendidikan dan Sosial Kemasyarakatan, 5 (1), 36-55.

Sulfemi, Wahyu Bagja. (2017). Analisis Pengaruh Motivasi dan Disiplin Terhadap Kinerja Guru (Studi Kasus di SMA Negeri 1 Pamijahan Kabupaten Kabupaten Bogor). Prosiding Seminar Nasonal STKIP Muhammadiyah Bogor. 1 (1), 342-357.

Sulfemi, Wahyu Bagja dan Ayu Hopilatul Lestari. (2017). Korelasi Kompetensi Pedagogik Guru dengan Prestasi Belajar Mata Pelajaran IPS Di SMP Muhammadiyah Pamijahan Kabupaten Bogor. Edutecno. 16 (1), 1-16

Sulfemi, Wahyu Bagja dan Abdul Qodir. (2017). Hubungan Kurikulum 2013 Dengan Motivasi Belajar Peserta Didik Di SMK Pelita Ciampea. Edutecno 17 (2), 1-8

Widaryanto dan Sulfemi, Wahyu Bagja (2016). Korelasi Penguasaan TIK Guru dengan Kemampuan TIK Peserta Didik. Edutecno. 14 (1), 1-10. 